\title{
Life Strategy of A Hygrophytic Moss: Orthotrichum sprucei Mont.
}

\author{
Mithat Evrim DEMIR*1 iD, Mesut KIRMACI ${ }^{2}$ iD, Adnan ERDAĞ ${ }^{2}$ \\ ${ }^{1}$ Aydin Adnan Menderes University, Buharkent Vocational School, Department of Plant and Animal \\ Production, Aydin, TURKEY \\ ${ }^{2}$ Aydin Adnan Menderes University, Faculty of Arts and Science, Department of Biology, Aydin, TURKEY
}

\begin{abstract}
\begin{tabular}{lll}
\hline Received: 12.04.2019 & Revised: 17.05.2019 & Accepted: 01.07.2019 \\
\hline
\end{tabular}
Abstract

A population of hygrophytic moss Orthotrichum sprucei Mont. was investigated in situ in one of two distribution areas in Turkey. The target species was observed for about 15 months to determine the population dynamics in Çine River Valley which was the first recorded locality. These hygrophytic species have developed an adaptation mechanism to regenerate and expand the population on Liquidambar orientalis Mill. and Platanus orientalis L. trunks which exposed to repetetive floods. To describe the biological adaptations which relies on the fact of decrease and increase of the population size, in vitro / ex situ experiments were carried and gemmae production ability that was not known before was observed. Propagation by means of fragmentation that is common among mosses was also observed in the species. The present study is very important being the first study on the biology of Turkish bryophytes.
\end{abstract}

Key words: Bryophyta, Orthotrichaceae, Orthotrichum, Orthotrichum sprucei, Biology, Turkey

\section{Higrofitik Bir Karayosunu Olan Orthotrichum sprucei Mont.’nin Yaşam Stratejisi}

$\ddot{\mathbf{O z}}$

Bir higrofitik karayosunu olan Orthotrichum sprucei Mont. türü, popülasyon dinamiklerini incelemek amacıyla Türkiyedeki iki yayılış yerinden birisi olan Çine Nehri Vadisinde yaklaşık 15 ay boyunca gözlenmiştir. Bu tür sıklıkla sele maruz kalan ağaç gövdeleri üzerinde bulunmakta ve popülasyonu artırma eğilimi göstermektedir. Popülasyon büyüklüğündeki azalma ve artışla ilgili olan biyolojik adaptasyonu açıklamak üzere in vitro / ex situ deneyler yapılmış ve daha önce bilinmeyen gemma üretme yeteneği tespit edilmiştir. Karayosunlarında yaygın olan fragmentasyon ile çoğalma özelliği de bu tür için gözlenmiştir. Yapılan çalışma Türk biryofitlerinin biyolojisi hakkında yapılan ilk çalışma olması bakımından önem taşımaktadır.

Anahtar kelimeler: Bryophyta, Orthotrichaceae, Orthotrichum, Orthotrichum sprucei, Biyoloji, Türkiye

\footnotetext{
* Corresponding author: medemir@adu.edu.tr

(C) 2019 All rights reserved / Tüm haklarl saklıdır.

To cite this article: Demir M.E. Kırmacı M. Erdağ A. 2019. Life Strategy of A Hygrophytic Moss: Orthotrichum sprucei Mont. Anatolian Bryology. 5:2, 65-73.

(c) (1) () This work is licensed under a Creative Commons Attribution-NonCommercial 4.0 International License.
} 


\section{Introduction}

Bryophytes, being most primitive land plants are represented all over the world with about 15.000 - 25.000 taxa. They can survive on almost every terrestrial locality including deserts and polar areas. Either their simple structures and their availability made them suitable for in situ (in vivo) and ex situ (in vitro) studies (Cuming, 2009). There are critical periods in the life cycle of mosses. In these periods response of plants may be different from normal conditions. Also, plants may develop different adaptations due to the stress condition they encounter. Numerous studies were done in order to understand the adaptation mechanisms that allow bryophytes to survive in unfavorable conditions. Studies on bryophytes in our country are predominantly on systematics. Studies on ecology, sociology and especially the biology of bryophytes are inadequate. Orthotrichum is the richest genus with 43 taxa (38 species, 2 subspecies and 3 varieties) among the Turkish Bryophytes (Erdağ and Kürschner 2017a; Erdağ and Kürschner, 2017b; Ellis et al., 2018). Orthotrichum sprucei Mont. was firstly reported from the study area (Çine/Aydın) in 2000 (Erdağ and Kürschner, 2000). It was recorded for the second time from Melendiz Mountain (Niğde) by Can et al., (2013). In the present study regeneration capacity of $O$. sprucei under stress conditions and life strategies were investigated.

\section{Material and Method}

This study was carried out in two stages. All life cycles and affected conditions are observed in their natural habitat for 15 months. In situ research was supported with in vitro experiments.

\subsection{In situ observations}

For in situ observations field works were done for 15 months to observe all life cycles of $O$. sprucei species. A tree (Platanus orientalis L.) which was holding $O$. sprucei species was chosen for observations (Figure 1). The area on tree bark that is rich with species is determined and bordered. Metal net whose dimensions are known is fixed to bordered area to ease counting of the species (Figure 2). Young and mature plants (with and without sporophytes) are counted and recorded individually along with necessary descriptions about environment and weather (climate, vegetation, water level etc). Counting was done using hand lenses, very small plants are omitted due to the risk of being different species.

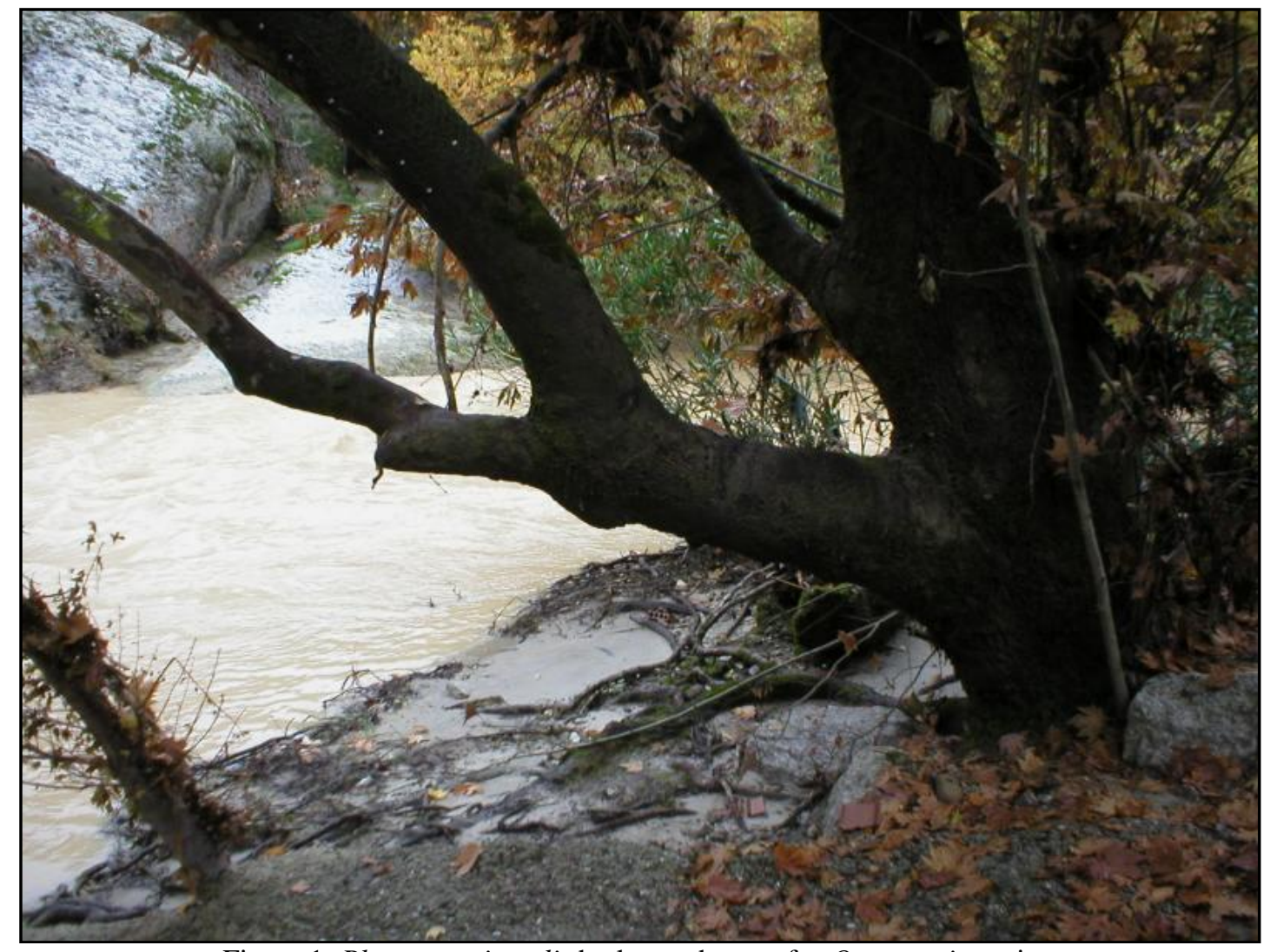

Figure 1: Platanus orientalis bark as substrate for $O$. sprucei species. 


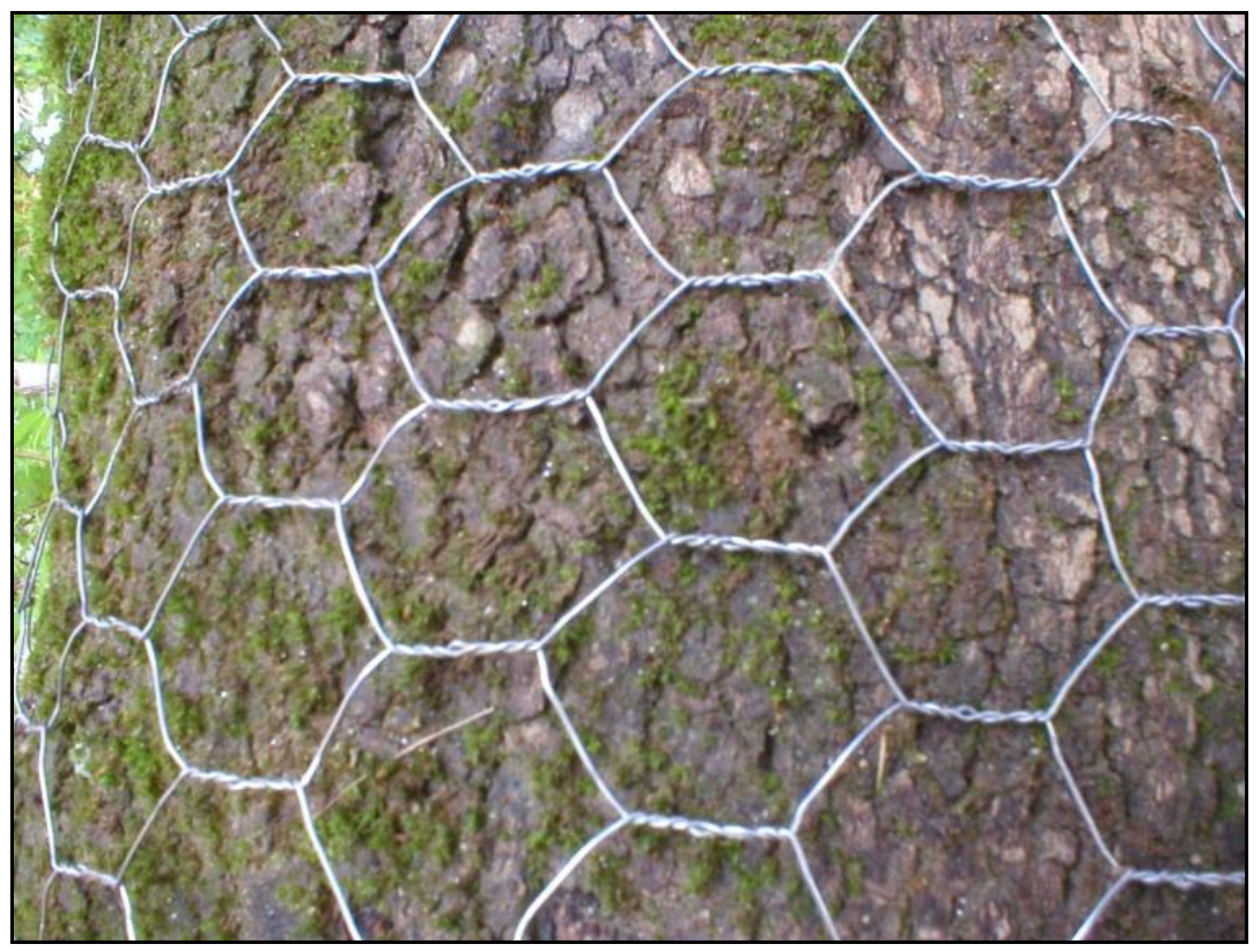

Figure 2: Fixed metal net on plant bark.

\subsubsection{Observation Area}

Observation area was about $2 \mathrm{~km}$ area in Çine Valley, recently Çine Dam reservoir area, located between East Menteşe (Madran) and West Menteşe (Gökbel) mountains (Figure 3, 4). Altitude above sea level of valley is about $250 \mathrm{~m}$ and also valley is north border of endemic plant Liquidambar orientalis. Seasonal rains increases water level up to 10 meters which can be seen with debris left on tree trunks. Increase in flow rate causes significant damage on branches of $P$. orientalis and L. orientalis. Observation area was reservoir area of Çine Dam, which were under construction in the study period. Dam construction was completed and retained water in the recent years (URL1). This area is under water and cannot be accesible today (Figure 5).

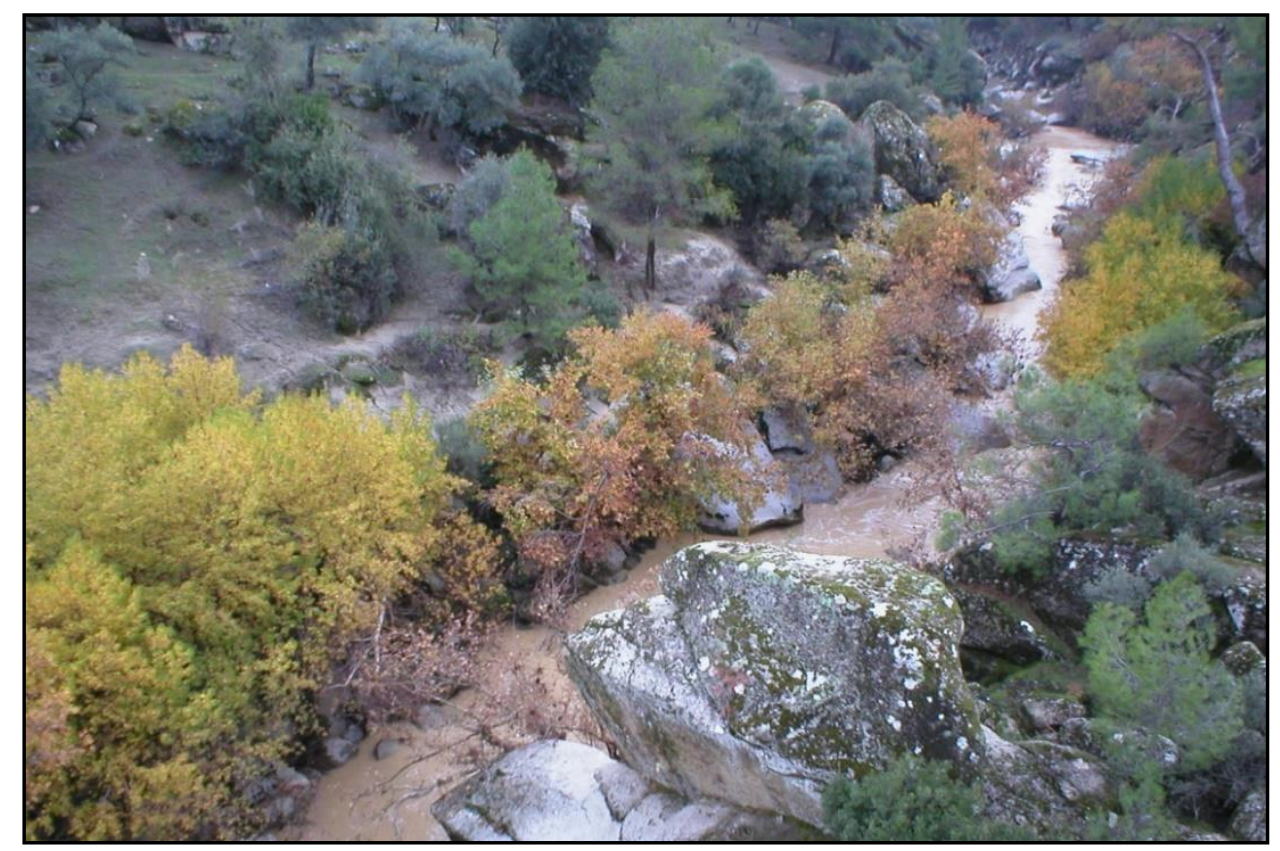

Figure 3: Top view of the observation area (2003). 


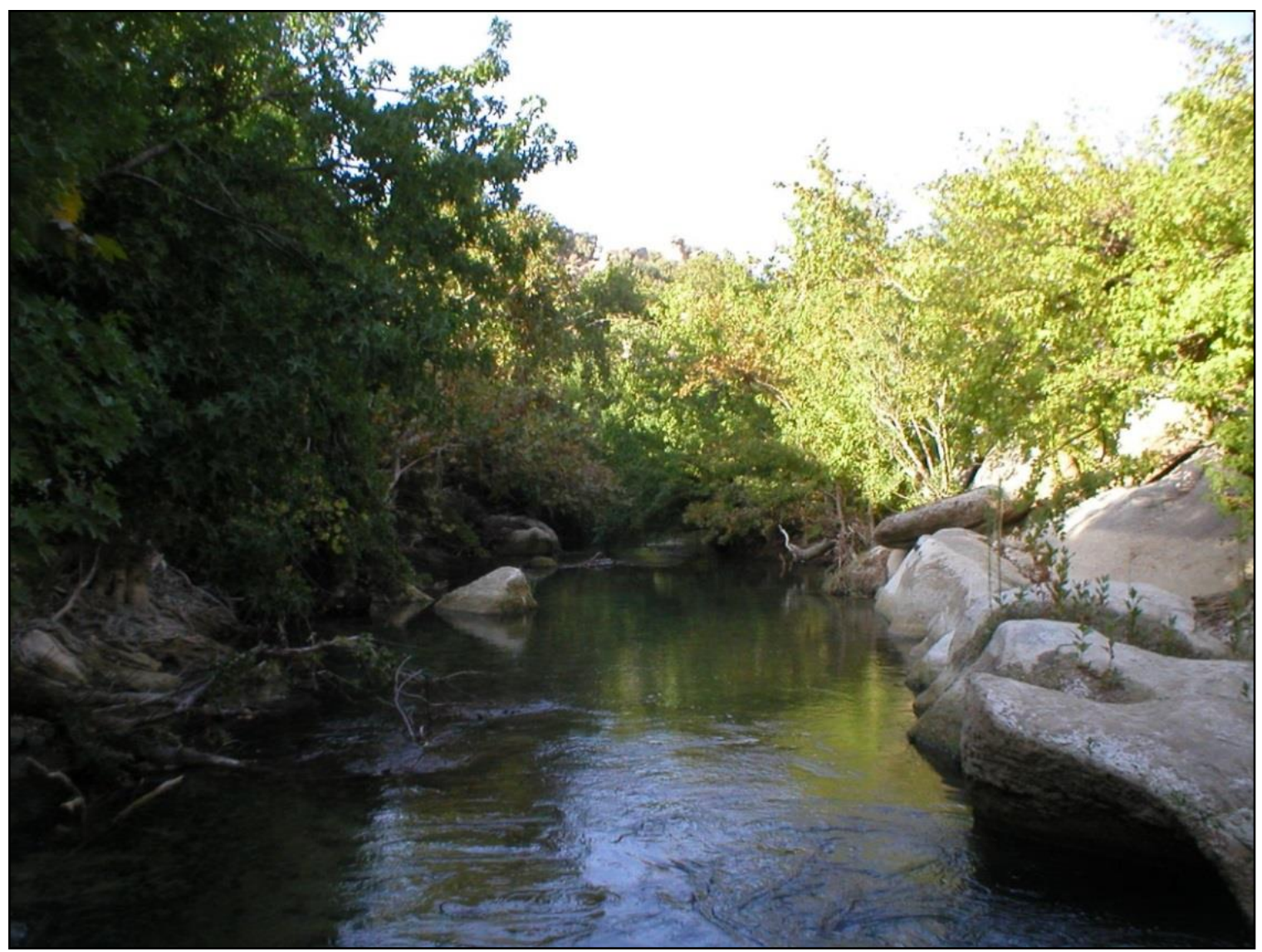

Figure 4: Valley view of the observation area (2003).

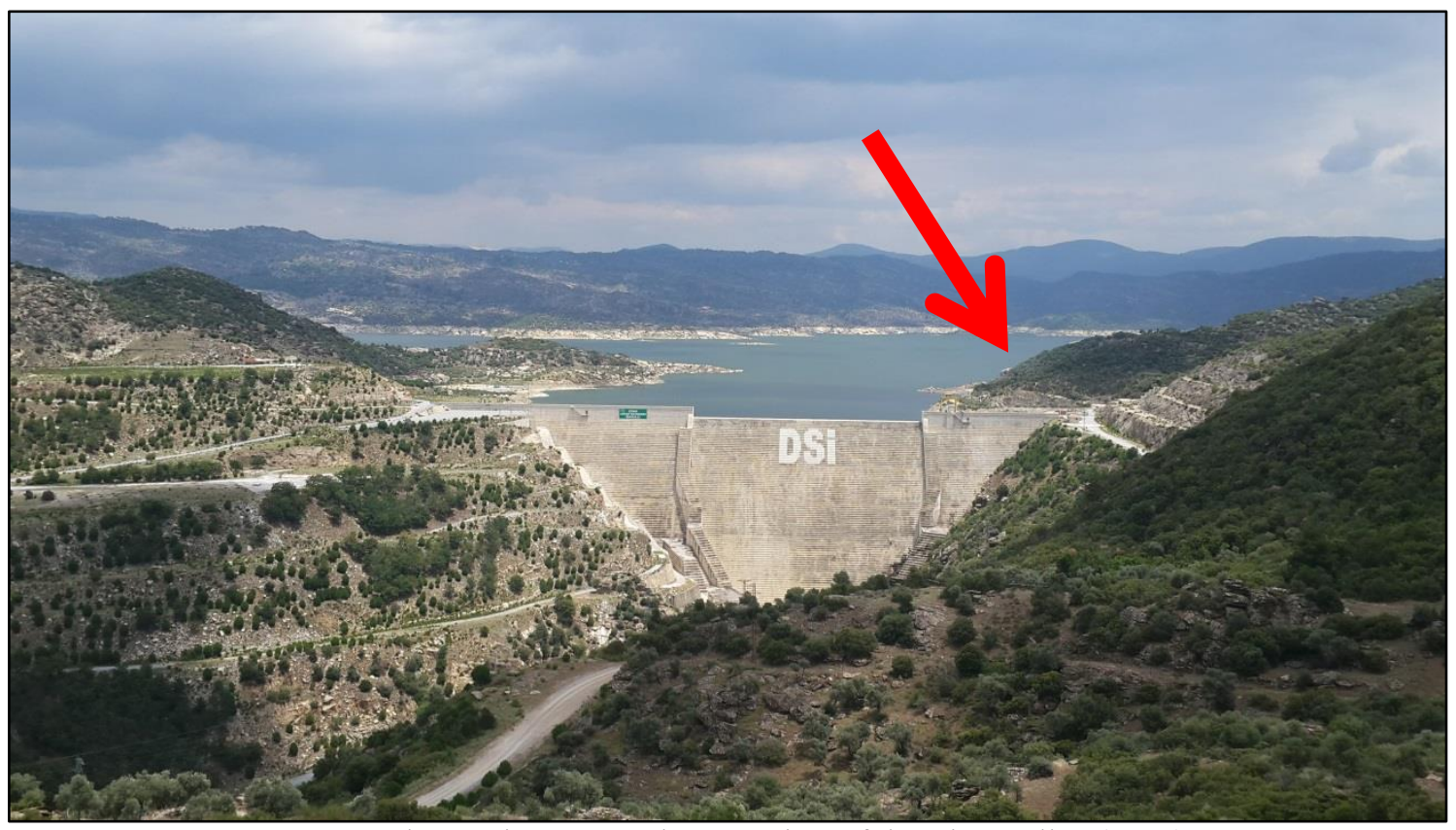

Figure 5: Observation area and recent view of the Çine Valley (2018). 


\subsection{In vitro experiments}

Observation of initial phases of bryophytes are biologically important. As they have microscopical structures which are difficult to observe in nature, in vitro experiments are conducted. Bryophyte samples were collected from field studies from Liquidambar orientalis and Platanus orientalis bark. Bryophyte samples were scratched out from bark, placed into plastic bags and brought to laboratory. Part of bryophyte species (leaves, roots, stem etc) and spores were used in in vitro cultures. All bryophyte samples were cleaned and dried before use. Samples were sterilised and transferred to petri dishes with nutrient media aseptically in laminar flow cabin. Murashige-Skoog (MS) were used as nutrient media (Murashige and Skoog, 1962). Petri dishes were kept in climate chamber with controlled temperature at $24 \pm 2 \mathrm{C}^{\circ}$ and photoperiod of $16 / 8$.

\section{Findings}

\subsection{In situ}

Population of $O$. sprucei were observed for 15 months in order to determine the response of the species which is highly exposed to severe ecological fluctiations (esp. floods). Young, mature and sporophyte bearing individual bryophyte samples were counted and recorded. In the beginning of the observation (November, 2003) number of individuals was 4209. Individual numbers over observation period is given in Figure 6.

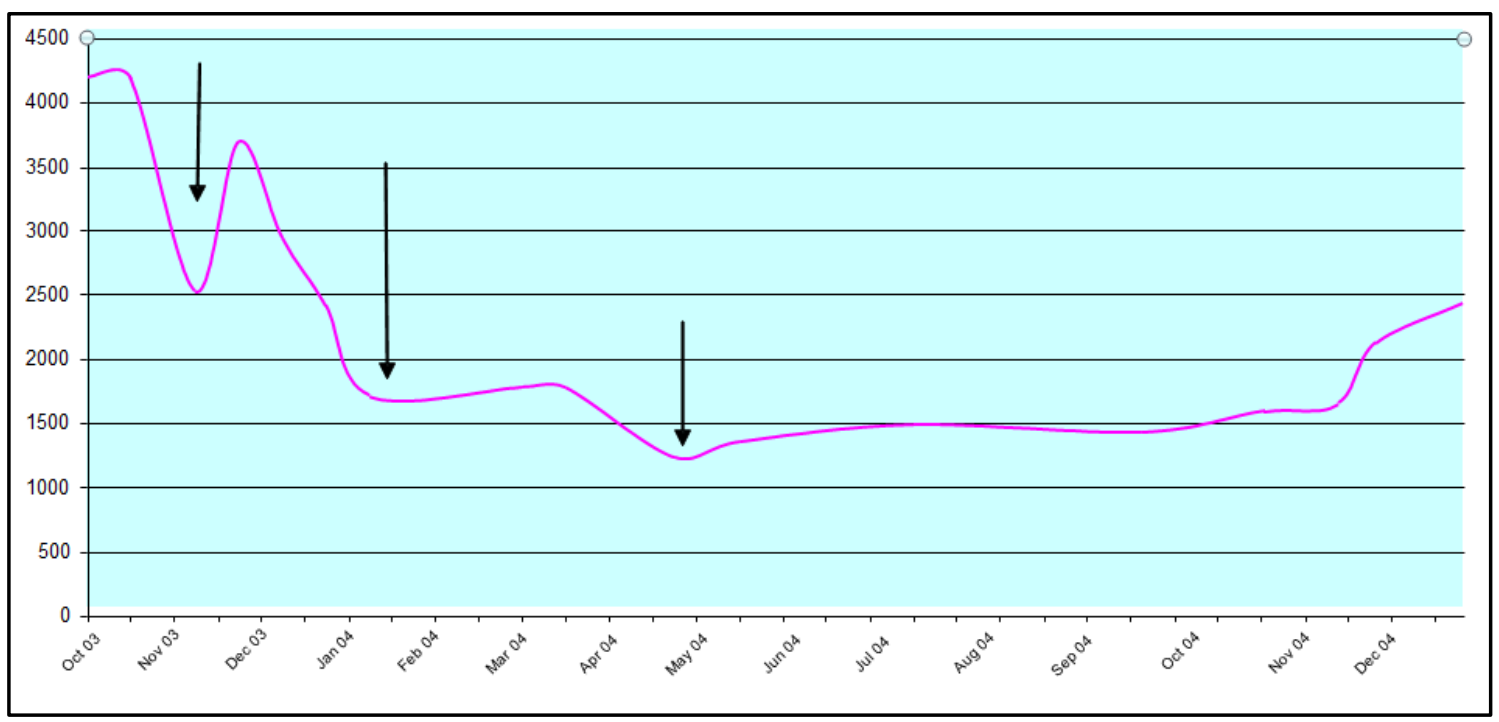

Figure 6: Individual numbers over observation period.

Number of individuals bearing sporophytes were also counted and recorded (Figure 7).

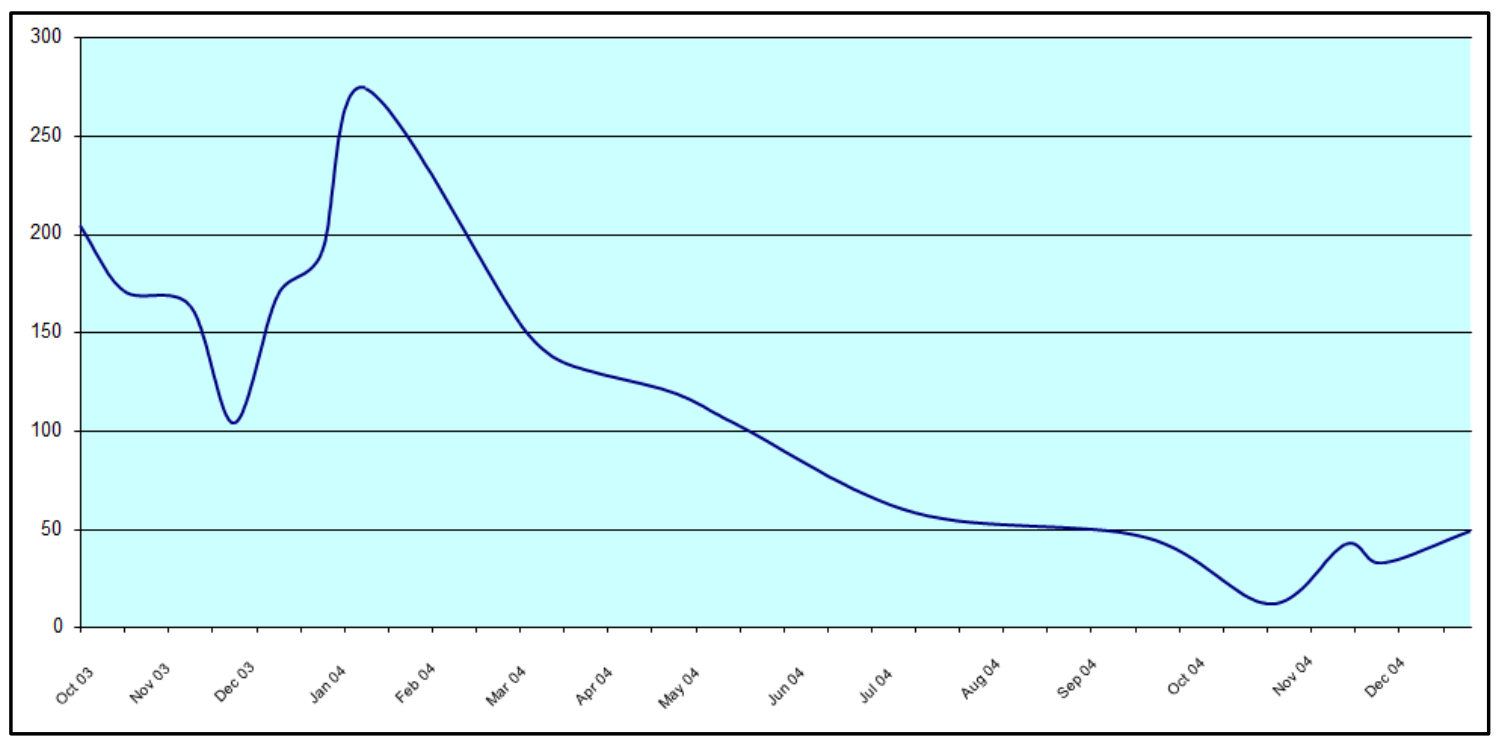

Figure 7: Number of individuals bearing sporophytes over observation period. 


\subsection{In vitro}

In vitro studies were performed to understand spore germination phases and asexual development arising from fragmentation, gemmae production etc. Mature plants (bearing mature sporophytes), mature but not sporophyte bearing plants and young plants were collected as described before. They were sown into different media including agar, distilled water and MS.

There is no accurate way of calculating spores in the sporophytes. Sporogen tissues of idealised capsule volume is used to calculate spore number. Spore production capacity of $O$. sprucei was calculated approximately 200.000 spores maximum, which is tought this number should be fewer under natural conditions. Spore production capacity is under influence of several factors including ecological, physiological and genetic factors.
Among all spores which were transferred to petri dishes, less than $1 \%$ of abnormality were observed.

Dead spores which are easily distinguished from living spores with their yellow-brown color and swelled spores which are in the first phase of germination can be seen in figures (Figure 8). Swelling spores extend its volume to two, sometimes to three times. In the following phase protonema tears spore membrane and projects from spore membrane. Swelling occurs in the fifth day after transferring to media and protonema development occurs in the following day. Shorter time also occurs in swelling (1-4 days) and protonema development (2-4 days). Swelling and protonema development are determined as successive and continuous phases.

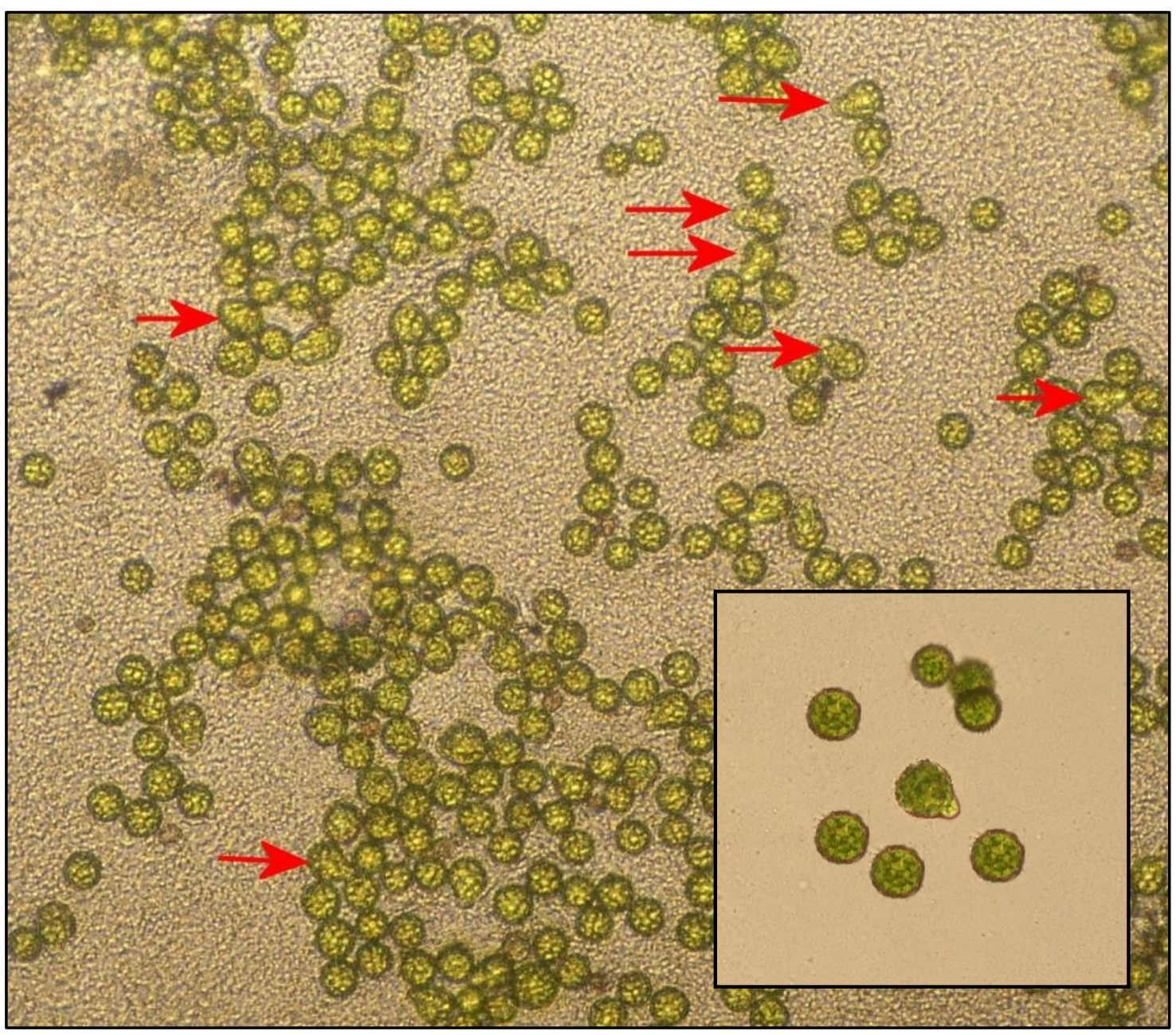

Figure 8: Germinating spores of $O$. sprucei 
10-15 days following protonema development, elongation of protonema became clear and swelled appearance of spore disappeared. Protonema is $4-5$ cells long in this phase.

Beginning from the first week after seeding, swelling were observed in leaf laminar cells.
Some of these laminar cells continue to protonema development resembling spore germination. Plant rhizoids also have similar protonemal development in first two weeks likewise plant explants (Figure 9).

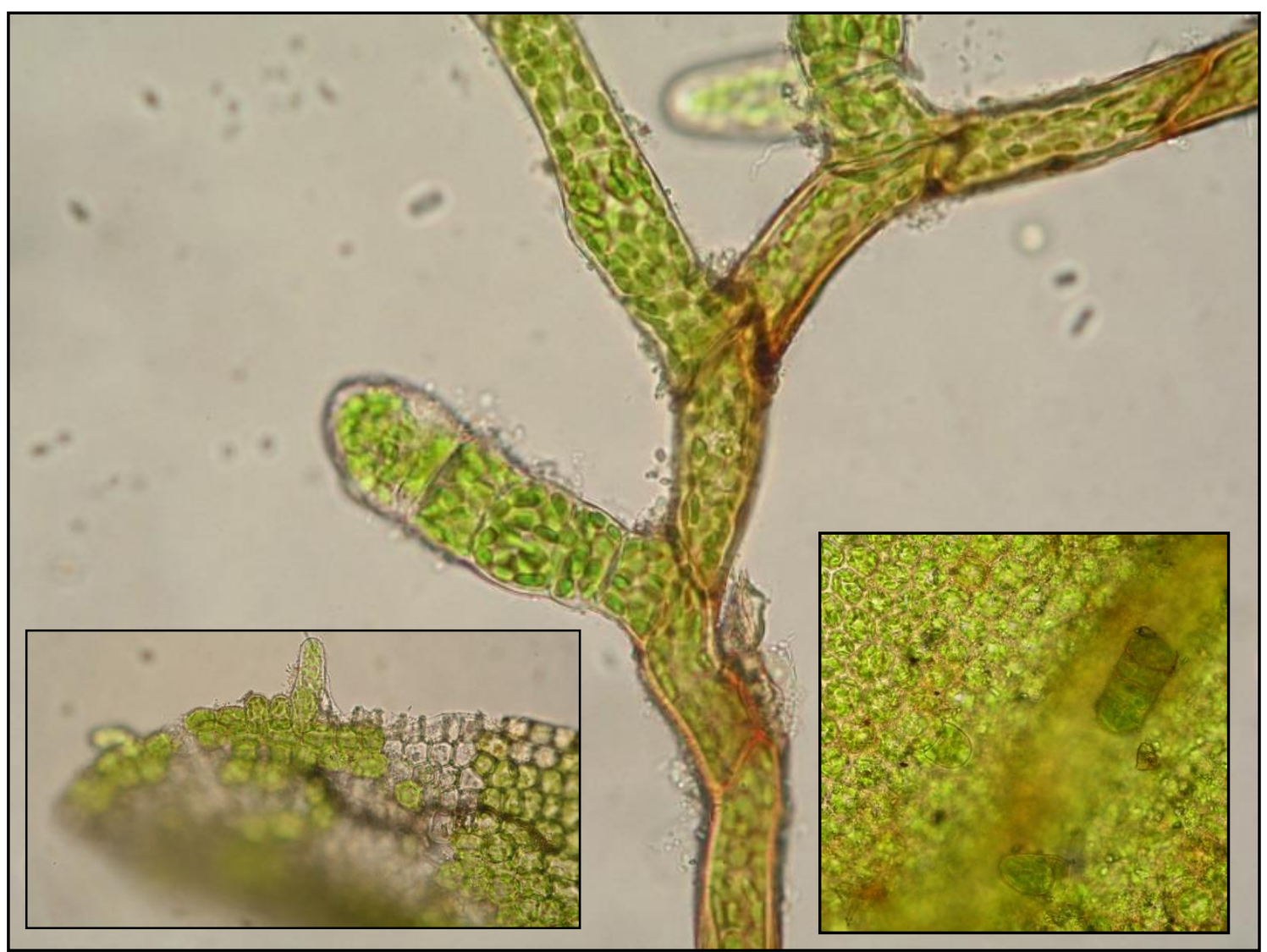

Figure 9: Protonema and gemmae development.

\section{Discussion and Results}

\subsection{In situ}

When individual numbers are anayzed, there were decreases and increases over time (Figure 6). Number of individuals tend to increase after losses. Primary reason for this population dynamics is environmental fluctuations. The determinative factor of the habitat is water, in other words flow rate of Çine river. River provides high humidity in habitat but rapid changes in flow rate makes important changes in demography of some organisms. Primary factor in decrease in number of individuals in first period is moderate floods in river. Flood can remove 10-15 meter tall trees and leave debris on tree branches even 5 meters high. Debris includes various organic materials (pieces of trees, weed, bush etc.) and important amount of sand. Sand has physiological effects beside its mechanical effect. It can cover plants and blocks sunlight which may cause inadequate or stopped photosynthesis leading to death. $\mathrm{pH}$ change due to mainly quartz content sand may also have side effects. Sand have abrasive effect when flowed with flood water over branches and could have wiped off some regions of population. Prominent demographic decreases indicated in the figure (November and January) shows two big flood occurence (Figure 6). The third narrowing in spring months is result of small floods indigenous to that region. When the graph is analyzed, it can be seen that first decrease is followed by rapid increase, second and third decrease is followed by slight increase. This high demographic increase could be explained only by high regeneration capacity of $O$. sprucei. Stability in population size at the end of spring season is result of slowing metabolic activities of the plant due to dry summer period. Decrease in water level of river can not provide enough 
moisture to upper region. The reason why $O$. sprucei is not expanding its population in summer period where the moisture is relatively continuous can be explained by its sporophyte production.

Sporophyte production is maximum in mid January (Figure 7). This period is the beginning of dormancy period so individual count is low. When number of individuals and sporophyte bearing individuals are analyzed together, it can be seen that population is mostly composed of mature plants and rate of young plants is decreasing. O. spruce $i$ is producing large number of spores and spreading them to substrate in summer months where there is no fluctuation as preparation for next fluctuating period. Only small amount of spores are germinated and some individuals continues maturation to sporophyte production phases. This period could be evaluated as dormant period.

Also when Figures are analyzed together, it can be seen that after first flood, the number of individuals and sporophyte bearing individuals are decreasing, in despite of rapid growth tendency, number of sporophyte bearing individuals continues to decrease. This phenomenon can be explained with mechanical damage of flood water which have severe effect on relatively bigger species, including sporophyte bearing individuals. In this period, plants particles (fragmantation), spores and every piece of plant that may function as gemmae are stimulated for asexual growth.

\subsection{In vitro}

Almost all of the species of the genus Orthotrichum produces sporophytes but they also continue to develop vegetative reproduction organs. In some sprecies sporophyte production is limited and gemmae production is dominant. Orthotrichaceae which is successful in both of reproduction methods is represented with many species in almost every continents.

Almost all of remaining spores were germinated in several weeks (approximately 5 weeks) in different periods. Early germination and late germination (delayed germination) of some spores could be explained with extending germination over a period of time which increases survival rate.

Protonema development were observed in leaf laminar cells and rhizoids. This phenomenon shows the efficiency of asexual reproduction in natural habitat. This observation also shows the function of fragmented gametophyte as propagules after flood damage.

Besides direct protonemal development of leaf explants, gemmae production which is common in mosses and related groups but not recorded before from $O$. sprucei were observed. As is known, gemmae is single or multicelled vegetative propagation structures which have potential to develop to mature individual like spores. Gemmae could be in different shapes and cellular organisations but in Orthotrichum species they are usually one-multicellular and filamentous structures. Gemmae production is used as secondary identification character in some cases, so it shouldn't be overlooked. In in vitro culture condition, factors which have an impact on production of gemmae is not clear but should be considered in further studies. In culture conditions, any laminar cell in plant leaf starts to swell and extends walls of margin cells and gets out, and with consecutive mitotic divisions typical filamentous multicelled Orthotrichum gemmae developes. This process starts in first week following seeding till second to third weeks. Costa margin cells are active in gemmae production. If gemmae production and fragmentation is compared, gemmae production have an advantage, as fragmantation is using multicelled leaf particles but gemmae is using only a few cells for propagation. The ratio of used plant part/new individuals is important especially in fluctiating habitats.

Our observations shown that in nature, gemmae reproduction process in $O$. sprucei might be faster because of damage of repetetive floods. There is few studies on the biology, ecology, ecophysiology and genetic studies of the bryophytes in Turkey. To understand adaptation to natural habitats of bryophytes should be supported with additional studies. The present study is very important being the first study on the biology of Turkish bryophytes.

\section{References}

Can S. M. Kara R. Ezer T. 2013. Bryophyte flora of Melendiz Mountain in Turkey. Turkish Journal of Botany. 37: 575-588.

Cuming A.C. 2009. Mosses as model organisms for developmental, cellular, and molecular biology: Bryophyte Biology. Goffinet B. Shaw A. J. Editors. Cambridge University Press. pp. 199-206.

Erdağ A. Kürschner H. 2017a. A reference list of Turkish bryophytes. The state of knowledge from 1829 until 2017. Anatolian Bryology. 3:2, 81-102. 
Erdağ A. Kürschner H. 2017b. Türkiye Bitkileri Listesi: Karayosunları. ANG Vakfi. İstanbul.

Ellis L. T. Agcagil E. Kırmacı M. Aleffi M. Bakalin V. A. Bednarek-Ochyra $\mathrm{H}$. Cykowska-Marzencka B Stryjak-Bogacka M. Bojaca G.F.P. Fantacelle L.B. ve ark. 2016. New national and regional bryophyte records, 49 . Journal of Bryology. 38:4, 327-347.

Erdağ A. Kürschner H. 2000. Orthotrichum sprucei Mont. (Orthotrichaceae, Musci), New to the Moss Flora of Turkey. Nova Hedwigia. 71:1-2, 145-150.

URL1. Devlet $\mathrm{Su}$ İşleri. 2017. Website: http://dsi.gov.tr/haberler/2017/04/11/141y\%C4\%B111\%C4\%B1k-r\%C3\%BCya$\% \mathrm{C} 3 \% \mathrm{~A} 7$ ine-adnan-menderesbaraj\%C4\%B1 [Accessed: 01 March 2019].

Murashige T. Skoog F. 1962. A revised medium for rapid growth and bio-assays with tobacco tissue cultures. Plant Physiology. 15: 437-497. 